\title{
Current reproductive isolation between ancestors of natural hybrids in Bacillus stick insects (Insecta: Phasmatodea)
}

\author{
BARBARA MANTOVANI*, FAUSTO TINTI†, MARINA BARILANI \& VALERIO SCALI \\ Università di Bologna, Dipartimento di Biologia Evoluzionistica Sperimentale, via Selmi 3, 1-40126, Bologna and \\ †Università di Bologna, Corso di Laurea in Scienze Ambientali, via Mafalda di Savoia 10, 1-48100, Ravenna, Italy
}

\begin{abstract}
Interspecific hybrids raise a variety of developmental, reproductive, and evolutionary issues. In Sicily, geographically and chronologically distinct hybridizations between the highly differentiated Bacillus rossius and $B$. grandii have produced hybridogenetic strains and clonal parthenogenetic species. In northern Sicily, all-female populations of facultatively parthenogenetic $B$. rossius and bisexual $B$. grandii benazzii co-occur and we could test their current hybridization through electrophoretic marker analyses; control crosses with allopatric males were also carried out. Hybrid female progeny percentages ranged from 0 to 74 being fewer in egg batches laid by parthenogenetic mothers than in those of amphimictic females; no difference was noticed between sympatric and allopatric pairs. $F_{1}$ hybrids of both sexes proved sterile; although some eggs started cleaving, no hemiclonal or clonal progeny hatched, only rare androgenetics being obtained. In currently produced hybrids a complete disruption of gametogenesis occurs, so that genetic constraints between parental taxa appear stronger now than in the past, most likely the result of ancestor evolution.
\end{abstract}

Keywords: genome evolution, hybridization, hybridogenesis, parthenogenesis, unisexual evolution.

\section{Introduction}

Speciation through hybridization, fertility and demographic advantages of unisexual hybrids are topics that evolutionary biologists have tackled recently, using morphological, genetic and molecular approaches (reviews in Bullini, 1985, 1994; Dawley \& Bogart, 1989; Bullini \& Nascetti, 1990; Scali et al., 1995). Interspecific hybrids arise when frequent heterospecific matings lead to the production of zygotes that occasionally overcome developmental constraints. Most natural hybrids show femalebiased or all-female progeny, as male gametogenesis and/or development are more severely affected by hybridization than female ones (see Coyne, 1994). Hybrid oogenesis also is altered, but it can happen that some eggs are functional and self-activating. A few hybrid progeny may thus hatch, whose descendants can persist in time and become a hybrid species if their modified gametogenesis stabilizes and their fertility increases in subsequent generations (Dawley

\footnotetext{
${ }^{*}$ Correspondence.
}

\& Bogart, 1989; Bullini \& Nascetti, 1990; Scali et al., 1995). Although gynogenetic and parthenogenetic hybrids are thought to be genetically isolated from their ancestors, reproductive interactions between them occur allowing hybrid genome evolution by addition of subgenomic fractions or of whole haplosets (Cimino, 1972; Quattro et al., 1992; Scali et al., 1995; Schartl et al., 1995; Tinti \& Scali, 1996). The very rare hybridogenetic hybrids produce reduced eggs by a modified gametogenesis allowing the transmission to the offspring of an unrecombined parental genome (hemiclone), the other one being completely discarded during oogenesis and sexually provided anew by host fathering males (reviews in Dawley \& Bogart, 1989; Scali et al., 1995).

The stick insects of the genus Bacillus provide a wide array of suitable taxa for analysing the relationships between ancestral and derived hybrid taxa. In Sicily, three different diploid hybrids originated from distinct hybridizations between the same species: $B$. rossius $(2 n=36, \mathrm{XX}$, female; $35, \mathrm{X} 0$, male) and $B$. grandii $(2 n=34, \mathrm{XX}$ female; $33, \mathrm{X} 0$ male) (Figs 1 , 2a). Parentals are quite differentiated genetically 


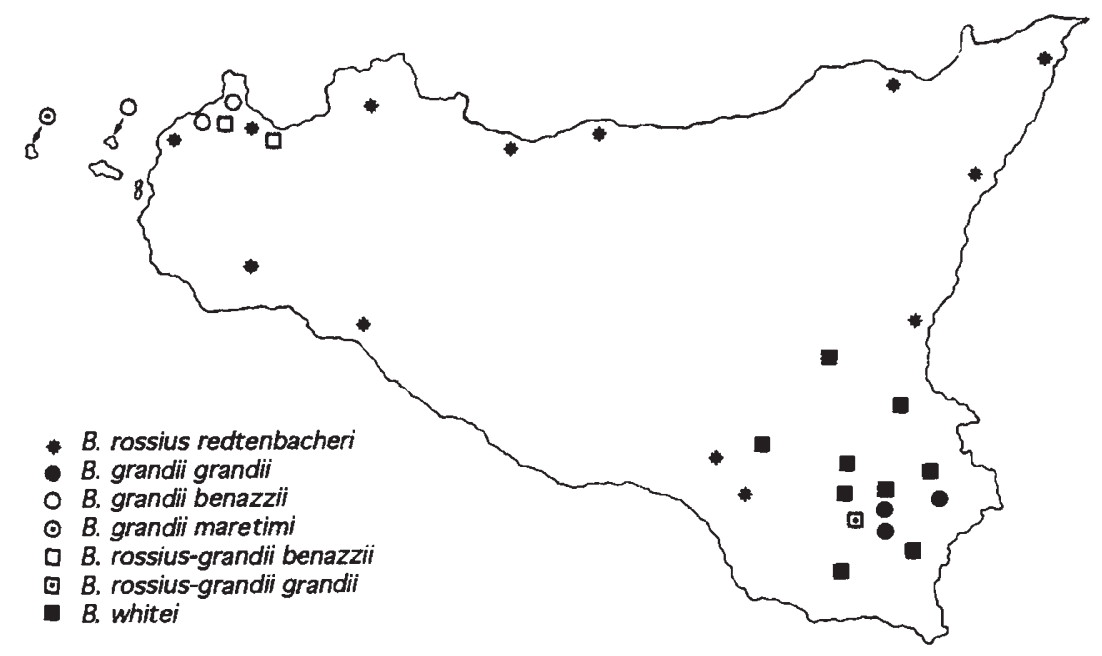

Fig. 1 Map of Sicily showing the distribution of amphimictic species (Bacillus rossius, B. grandii) and their allodiploid hybrids.
(Nei's distance $=1.25-1.65$; Mantovani \& Scali, 1993); $B$. grandii is strictly bisexual, whereas $B$. rossius has also all-female, facultatively parthenogenetic populations. Bacillus rossius-grandii benazzii and $B$. rossius-grandii grandii are hybridogenetic strains consisting of allodiploid females $(2 n=35)$. They segregate the parental genomes and pass to the progeny the unrecombined rossius genome while discarding the grandii one (Fig. 2b); the rare, hybridogenetically derived hybrid males $(2 n=34)$ are almost completely sterile (Mantovani \& Scali, 1992; Tinti \& Scali, 1992, 1995). The third interspecific natural hybrid is the clonal parthenogenon $B$. whitei ( $=B$. rossius/grandii grandii; $2 n=35$ ) (Nascetti \& Bullini, 1982); it derives from an older hybridization event and reproduces by an automictic mechanism in which parental genome segregation takes place in a very similar way to that realized by hybridogens (reviews in Scali et al., 1992, 1995) (Fig. 2c). Moreover, Bacillus allodiploids share the ability of producing a nonhybrid all-paternal offspring of both sexes (androgenetics) when mated to males of the parental species (Tinti \& Scali, 1996) (Fig. 2d).

Allozyme and cytological analyses have clearly revealed the hybrid origin of Bacillus allodiploids, because parental species show diagnostic alleles at 18 of 20 loci analysed, as well as differences in chromosome number and morphology. Electrophoretic analyses have shown no differentiation either between the rossius gene pool of the three hybrids and that of Sicilian B. rossius, or between the grandii gene pool embodied in $B$. whitei and that of the sympatric $B$. grandii grandii, thus suggesting a rather recent origin of the hybrids (reviewed in Scali et al., 1995). On the other hand, laboratory crosses between $B$. rossius and $B$. grandii produce abundant but sterile hybrid progeny, as repeatedly stated by Bullini \& coworkers (Bullini, 1985, 1994; Nascetti et al., 1985). Actual data on 'synthetic' B. whitei have never been published, however, so that the number of progeny and crosses, as well as the origin of mating partners remains unknown.

We discovered some areas in which all-female populations of $B$. rossius, the bisexual $B$. grandii benazzii and the hybridogenetic $B$. rossius-grandii benazzii females actually live in the same bushes. The occurrence of mixed natural populations and the lack of premating constraints between heterospecific partners (Scali et al., 1995), prompted us to test the current hybridization rate between the two ancestral species and the fertility level of the newly produced hybrids.

\section{Materials and methods}

Matings were carried out between $B$. rossius females and $B$. grandii males, because the genome exclusion of hybridogenetics and the current population structure suggest that $B$. rossius is the maternal ancestor. Sixteen $B$. rossius redtenbacheri females $(r r)$ were crossed with either B. grandii benazzii ( $g b$; Scopello, TP, Italy: crosses $\mathrm{C} 1-10$ ) or $B$. grandii grandii males (gg; Canicattini Bagni, SR, Italy: crosses C 11-16). Among females, 13 were facultatively parthenogenetic: nine derived from the area of syntopy with B. grandii benazzii (Scopello, TP, Italy: crosses C1-8, C11) and four from allopatric demes (Cefalú, PA, Italy: cross $\mathrm{C} 12$; Castelvetrano, $\mathrm{TP}$, Italy: cross $\mathrm{C} 13$; Isola Capo Rizzuto, CZ, Italy: cross C15; Piran, Croatia: cross $\mathrm{C} 16$ ); the three remaining allopatric 
Fig. 2. Origin and reproduction of allodiploid Bacillus stick insects. (a) Diagram of hybridization events between amphimictic parents (Am), originating hybridogenetic $(\mathrm{Hy})$ and parthenogenetic (Pa) strains. (b-d) Diagrams of cytological mechanisms of the three main reproductive modes $(\mathrm{r}$, rossius haploset; $\mathrm{g}, \mathrm{g}^{\prime}$ and $\mathrm{g}^{\prime \prime}$, grandii haplosets).
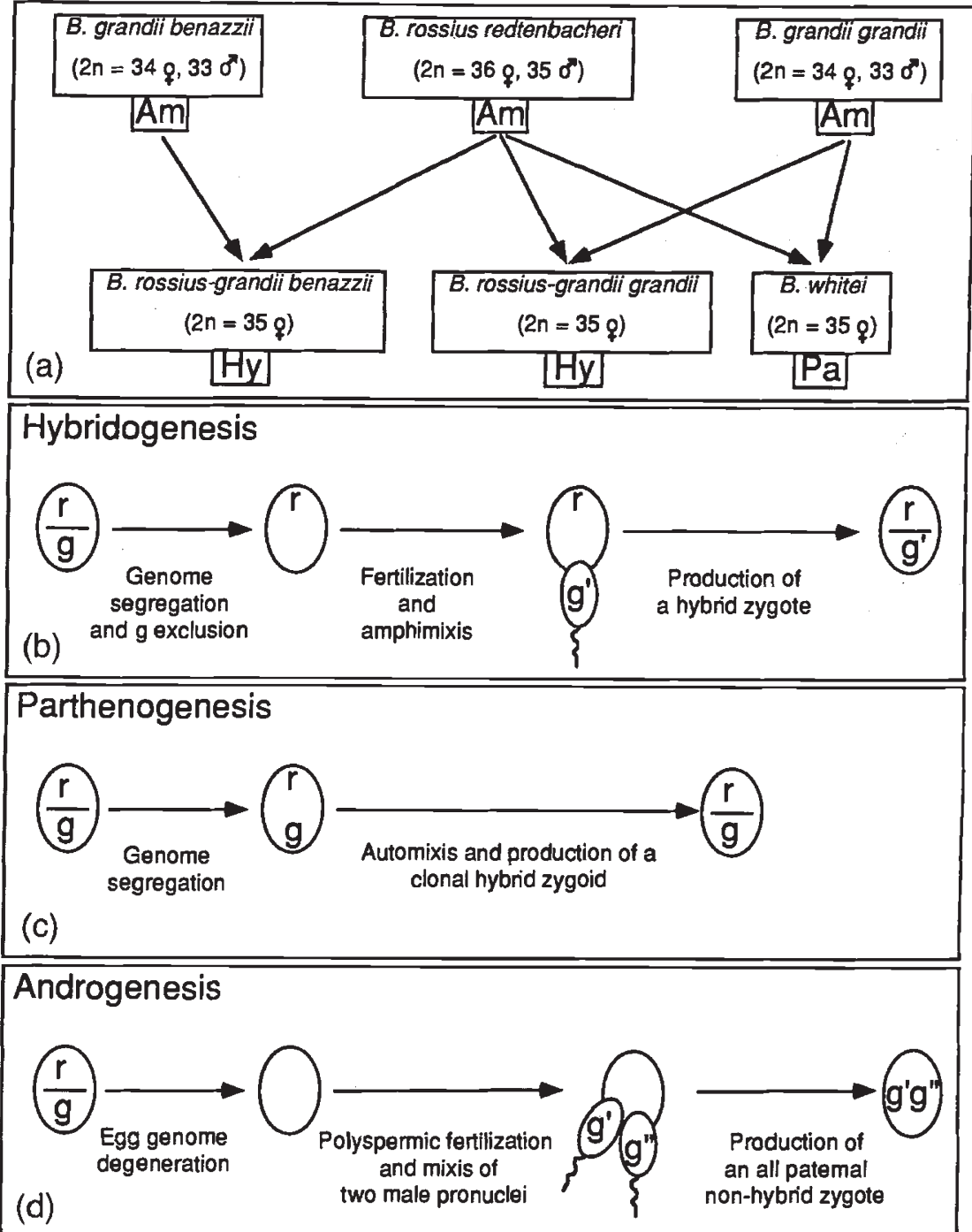

females derived from the closest bisexual population (Gorghi Tondi, TP, Italy: crosses C9, 10, 14). The actual number of crosses was limited by the very long generation time, which can span over 2 years because of the embryonic diapause (Scali, 1968), and also by the premature death of a few partners. Pairs were kept in well aerated cages $(30 \times 30 \times 45 \mathrm{~cm})$ on fresh foodplants (bramble, lentisk) at natural photoperiod, temperature and moisture conditions. No behavioural differences between homospecific and heterospecific copulating pairs were noticed and all partners were actually observed in copula at least once. The actual occurrence of fertilization was checked in some egg batches by DAPI staining of sperm (Scali \& Tinti, 1992). Eggs were collected weekly and maintained in transparent plastic vials under the same conditions as adults; hatched larvae were collected daily and for most of them their sex was ascertained at once; almost a third of progeny were analysed electrophoretically, whereas the others were left over for backcrosses and karyology.

Parents were genetically characterized using as markers phosphoglucomutase (PGM, EC 5.4.2.2, locus Pgm) and glucose-6-phosphate isomerase (GPI, EC 5.3.1.9, locus Gpi) allozymes. Electrophoretic procedures and allele nomenclature were after Mantovani \& Scali (1993).

To test the reproductive modes of $F_{1}$ progeny, virgin egg batches from five of the 11 egg-laying females were obtained (Table 2); six other such females and one male were backcrossed to various specimens of parental species (Table 3, B1-6; B8), whereas another $F_{1}$ male was mated to a hybridogenetic $B$. rossius - g. grandii female (Table $3, \mathrm{~B} 7$ ). 
Cytological analyses were carried out on embryos and hybrid adults to check developmental stages and gametogenetic processes, respectively. Chromosome and ovariole photos were taken on Kodak 100 ISO films.

Statistical analyses were carried out by means of $\chi^{2}$-tests, applying Yates' correction when required. The variability of hybrid female proportion (HFP) in $F_{1}$ progeny (Table 1 ) was tested using the $G$-statistics (Sokal \& Rohlf, 1981).

\section{Results}

\section{$F_{1}$ offspring analysis}

In total, 3248 eggs were laid, from which 2576 larvae hatched; descendants showed a sex ratio significantly skewed toward females $(P<0.001$, Table 1$)$; this feature was common to all families with the only exception of $\mathrm{C} 10 \quad(0.05<P<0.10)$. Crosses of parthenogenetic females had high hatching percentages, whereas those involving amphimictic partners shared significantly lower values $(\mathrm{C} 9,10,14$; $P<0.001)$.

Genetic marker analyses carried out on 745 individuals revealed that in all crosses but two, parthenogenetic offspring were the majority and that all males were hybrid of mictic origin (Table 1). In three crosses hybrid females significantly outnumbered males $(\mathrm{C} 4,8,12$; Table 1$)$; this was also true for the overall hybrid progeny $(0.001<P<0.01)$. The proportion of hybrid females (HFP) ranged from 0 to 74.4 per cent (crosses C3 and 10, respectively), with a high heterogeneity among matings $(r r \times g b$ crosses: $G_{\mathrm{H}}=5154.9,8$ d.f., $P<0.001 ; r r \times g g$ crosses: $G_{\mathrm{H}}=754.7,3$ d.f., $\left.P<0.001\right)$. The same range of hybrid variability was observed in crosses between

Table 1 Hatching percentages, sex ratios, type of descendants and genetic markers analysis of 16 crosses between Bacillus rossius redtenbacheri females $(r r)$ and males of $B$. grandii benazzii $(g b, \mathrm{C} 1-10)$ or $B$. grandii grandii $(g g, \mathrm{C} 11-16)$

\begin{tabular}{|c|c|c|c|c|c|c|c|c|c|}
\hline \multirow{3}{*}{$\begin{array}{l}\text { Cross and } \\
\text { genetic markers }\end{array}$} & \multirow{2}{*}{\multicolumn{3}{|c|}{$\begin{array}{l}\text { Parental taxa and } \\
\text { genotype structure }\end{array}$}} & \multicolumn{6}{|c|}{ Offspring } \\
\hline & & & & \multirow{2}{*}{$\begin{array}{l}\text { Hatching } \\
(\%)\end{array}$} & \multicolumn{2}{|c|}{ Sex ratio } & \multicolumn{2}{|c|}{ Tested females } & \multirow{2}{*}{$\begin{array}{l}\mathrm{HFP} \\
(\%)\end{array}$} \\
\hline & q & $x$ & $0^{*}$ & & $\hat{o ̂}$ & qq & NH & $\mathrm{H}$ & \\
\hline & $r r$ & $x$ & $g b$ & & & & & & \\
\hline $\mathrm{C} 1$ & SynP & $x$ & & 90.3 & 3 & 136 & 135 & 1 & 0.7 \\
\hline $\mathrm{C} 2$ & SynP & $x$ & & 92.0 & 0 & 121 & 120 & 1 & 0.8 \\
\hline C3 & SynP & $x$ & & 91.4 & 0 & 228 & 92 & - & 0.0 \\
\hline $\mathrm{C} 4$ & SynP & $x$ & & 99.2 & 9 & 342 & 133 & 8 & 5.7 \\
\hline C9 & AllA & $x$ & & 55.8 & 22 & 116 & 41 & 18 & 30.5 \\
\hline$G p i$ & $100 / 100$ & $x$ & $84 / 84$ & & & & $100 / 100$ & $100 / 84$ & \\
\hline Pgm & $100 / 100$ & $x$ & $118 / 118$ & & & & $100 / 100$ & $100 / 118$ & \\
\hline $\mathrm{C} 5$ & SynP & $x$ & & 96.6 & 9 & 43 & 28 & 10 & 26.3 \\
\hline C6 & SynP & $x$ & & 97.0 & 19 & 98 & 38 & 4 & 9.5 \\
\hline $\mathrm{C} 7$ & SynP & $x$ & & 95.0 & 16 & 95 & 37 & 3 & 7.5 \\
\hline $\mathrm{C} 8$ & SynP & $x$ & & 93.1 & 33 & 95 & 15 & 26 & 63.4 \\
\hline $\mathrm{C} 10$ & AllA & $x$ & & 59.3 & 58 & 80 & 10 & 29 & 74.4 \\
\hline \multirow[t]{2}{*}{$G p i$} & $100 / 100$ & $x$ & $78 / 84$ & & & & $100 / 100$ & $100 / 78$ & \\
\hline & & & & & & & & $100 / 84$ & \\
\hline \multirow{2}{*}{$P g m$} & $100 / 100$ & $x$ & 118/118 & & & & $100 / 100$ & $100 / 118$ & \\
\hline & $\begin{array}{c}r r \\
\text { SunP }\end{array}$ & $x$ & $g g$ & & & & & & \\
\hline C11 & SynP & $x$ & & 94.5 & 5 & 97 & 30 & 2 & 6.3 \\
\hline $\mathrm{C} 12$ & AllP & $x$ & & 83.9 & 19 & 136 & 25 & 11 & 30.6 \\
\hline $\mathrm{C} 13$ & AllP & $x$ & & 91.6 & 9 & 142 & 49 & 7 & 12.5 \\
\hline C14 & AllA & $x$ & & 24.0 & 2 & 84 & 45 & - & 0.0 \\
\hline C15 & AllP & $x$ & & 95.6 & 1 & 167 & 22 & - & 0.0 \\
\hline $\mathrm{C} 16$ & AllP & $x$ & & 60.8 & 2 & 42 & 8 & 1 & 11.1 \\
\hline$G p i$ & $100 / 100$ & $x$ & $84 / 84$ & & & & $100 / 100$ & $100 / 84$ & \\
\hline
\end{tabular}

A, amphimictic; All, allopatric; $\mathrm{H}$, hybrid; HFP, proportion of hybrid females; $\mathrm{NH}$, nonhybrid; $\mathrm{P}$, facultative parthenogenetic; Syn, syntopic. Figures refer to allozyme mobility and identify parental and offspring marker genotypes. 
syntopic and allopatric partners. Mean values of HFP are low in both $r \times g b$ and $r r \times g g$ crosses (13.4 and 10.5 per cent, respectively), with no significant difference between them. However, amphimictic females derived from populations geographically close to the range of fertilizing males $(\mathrm{C} 9,10$; Table 1 ), produced very high numbers of hybrids, which did significantly differ from those obtained from the corresponding crosses with parthenogenetic females

Table 2 Cytological analysis of virgin (C5-9) or fertilized eggs (C7-9, backcrosses B1-5, Table 3) laid by Bacillus rossius/grandii $\mathrm{F}_{1}$ hybrid females

\begin{tabular}{lrccc}
\hline & & \multicolumn{3}{c}{ Developmental stage } \\
\cline { 3 - 5 } $\begin{array}{l}\text { Hybrid } \\
\text { female }\end{array}$ & $\begin{array}{c}\text { Batch } \\
\text { size }\end{array}$ & ND & ES & CD \\
\hline C5 & 5 & 3 & 2 & \\
C7 & 11 & 1 & 9 & \\
C8 & 33 & 3 & 7 & \\
C9 & 15 & 3 & 8 & \\
C9 (B1) & 25 & 4 & 6 & \\
C8 (B2) & 6 & 4 & 1 & \\
C8 (B3) & 20 & 1 & 2 & \\
C8 (B4) & 17 & 6 & 6 & 1 \\
C7 (B5) & 3 & 1 & 1 & \\
\hline
\end{tabular}

ND, no visible development; ES, early stages (blastula); $\mathrm{CD}$, complete development (pigmented, fully formed embryo).
$(P<0.001)$; it is to be noted, however, that this test compares 276 vs. 1247 descendants.

In spite of a quite normal size of testes of $F_{1}$ hybrids (only two males of ten had reduced gonads), their cytological analysis showed meiotic metaphases I with a high number of unpaired chromosomes and few multivalent associations (Fig. 3a).

\section{Fecundity and fertility of the $F_{1}$ adults}

Anatomical dissection of 18 females reared to maturity revealed that seven of them were completely sterile, having no growing oocytes (Fig. $3 b)$. The other 11 females showed a partial fecundity because a few of the about 70 ovarioles contained full-grown yolky eggs. None of the 97 virgin eggs laid by these females hatched. Nevertheless, cytological analysis of egg samples revealed that the majority of them did start development (26 of 36; Table 2) and showed living cells; no dividing nuclei, suitable for chromosome counts, were found however.

From 82 eggs laid by hybrid $F_{1}$ females backcrossed to parental species males (B1-6, Table 3 ) no amphimictic or gynogenetic offspring were obtained; progeny of cross B4 were actually androgenetics, i.e. had an all-paternal genetic constitution. Cytological analysis of unhatched eggs of fertilized backcross batches again showed that over half of them started cleavage (17 of 33; Table 2 ).

Table 3 Number of eggs, hatching percentages, sex ratios, type of descendants and genetic markers analysis of eight matings involving hybrid females or males ( $r / g b ; r r / g g)$, derived from Table 1 crosses, and $B$. rossius redtenbacheri ( $r$ ), $B$. grandii benazzii ( $g b)$, B. grandii grandii (gg), or B. rossius-grandii grandii ( $r$ r-gg) partners

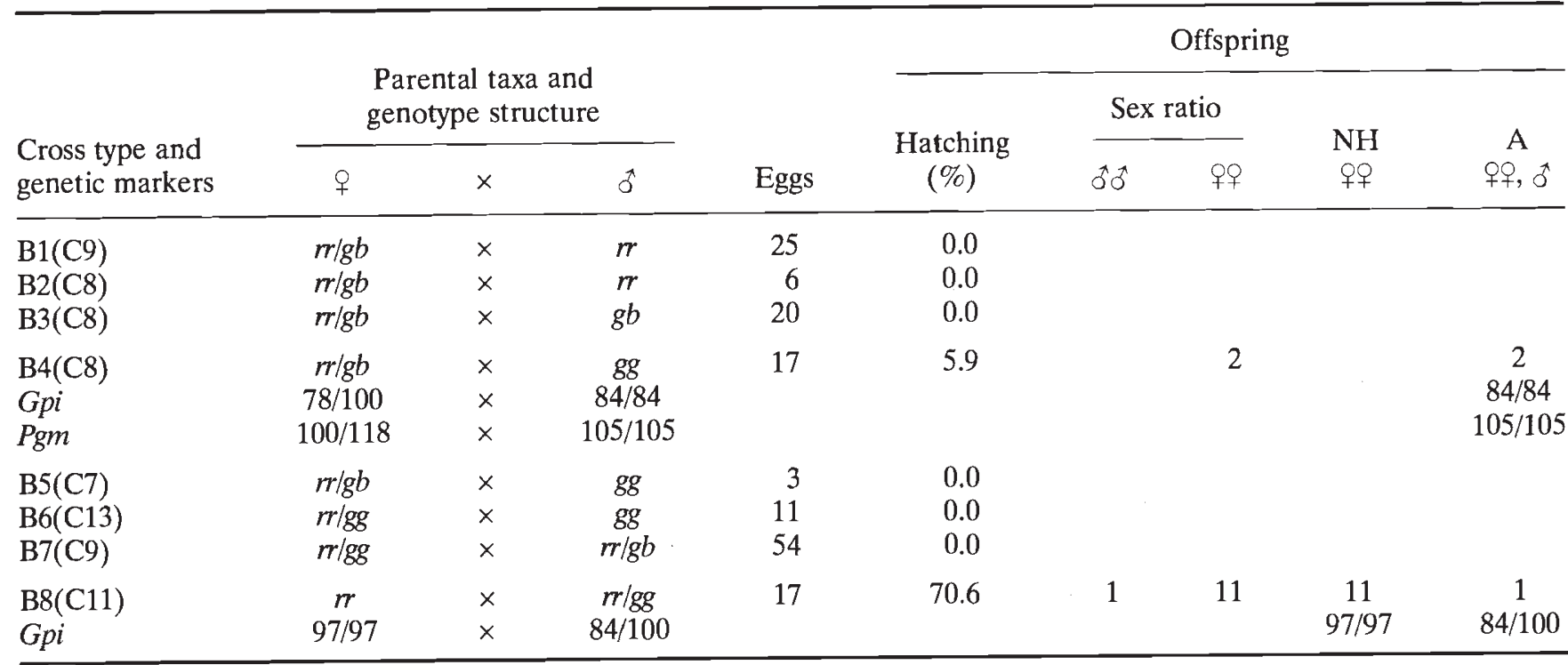

$\mathrm{NH}$, nonhybrid; A, androgenetic. Figures refer to allozyme mobility and identify parental and offspring marker genotypes.

(C) The Genetical Society of Great Britain, Heredity, 77, 261-268. 

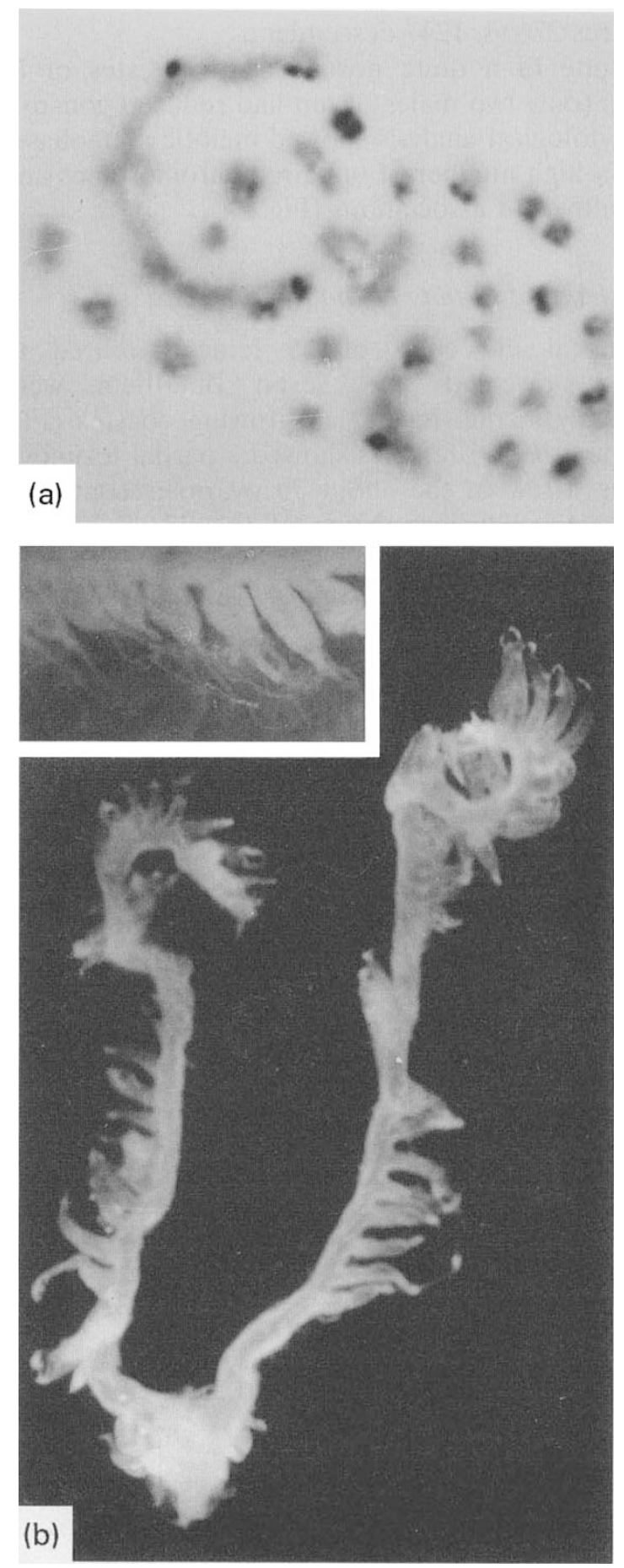

Fig. 3. (a) Meiotic metaphase I of a Bacillus rossius redtenbacheri/grandii benazzii hybrid male. Asynapsis is widespread but a few multivalent and nonhomologous associations are formed ( $\times 2000$; Giemsa stain). (b) Typical appearance of ovaries of sterile $B$. rossius/grandii females. Note the complete absence of vitellogenic oocytes $(\times 4$; inset $\times 15)$.
Crosses involving $F_{1}$ hybrid males also gave no amphimictic offspring (B7 and 8, Table 3 ): no hatching was actually obtained from cross B7, whereas allozyme markers demonstrated that among B8 progeny females were of parthenogenetic origin $\left(G p i^{97 / 97}, r r\right)$ and the unique male had an androgenetic derivation $\left(G p i^{84 / 100}, r r / g g\right)$.

\section{Discussion}

The production of hybrid offspring shows a great heterogeneity among matings (Table 1). Actually, the majority of descendants are nonhybrid, facultatively parthenogenetic females. As a matter of fact, $F_{1}$ hybrid females produced 82 eggs (Table 3 ), which either did not hatch (80) or gave birth to androgenetic females; therefore, on the whole, no gene from $F_{1}$ hybrid females passed to progeny. The unique hybrid specimen obtained from an $F_{1}$ parent was a male androgen with the same heterozygous structure as the father $\left(G p i^{84 / 100} ; \mathrm{B} 8\right.$, Table 3$)$. Such an all-paternal male apparently originated through the 'all-male clonal androgenesis', which relies on unreduced sperm-nuclei and appears to be an evolutionary blind alley (Tinti \& Scali, 1995). Therefore, no fertile hybrids were produced among the 2576 descendants obtained from 16 crosses.

In the past the same species produced fertile hybrid females which persisted as hemiclonal or clonal hybrids. The lack of fertile hybrids could be explained by the limited experimentation, but it could also suggest that an increased differentiation between parental genomes has occurred (see Moritz et al., 1989). Given the absence of allozyme differences between modern and ancient Bacillus parental species, it could be further argued that other genome components are crucial for setting reproductive isolation (Scali et al., 1995).

This may be of wider occurrence in natural hybrids, as the re-creation of fertile hybrids has only been possible in Poeciliopsis monacha-lucida, Lacerta saxicola and Muellerianella unisexual complexes (Schultz, 1973; Drosopoulos, 1978; Darewsky, 1983); in all three cases the fertile 'synthetic' hybrids showed the same gametogenetic features as the natural ones.

Mutations allowing the production of genomically balanced gametes in a parthenogen, either hybrid or nonhybrid, could change only one or few steps of a genetically controlled, though not rigidly determined, system. The hypothesis forwarded by Bullini \& Nascetti (1990) bridging spontaneous and hybrid parthenogenesis is the closest to our views on Bacillus unisexuals, but it does not envisage that both

(C) The Genetical Society of Great Britain, Heredity, 77, 261-268. 
types of parthenogenesis could originate from the same kind of mutations triggered by a variety of physical or biological conditions. Furthermore, Bullini \& Nascetti's hypothesis does not accept that hybridization itself may represent a trigger for those cell cycle/division mutants which rescue hybrid gametogenesis from complete failure. On the basis of our extensive cytological observations on Bacillus unisexuals (Marescalchi et al., 1991; Tinti \& Scali 1992, 1995; Scali et al., 1995) we suggest that in Bacillus hybrids, hybridogenesis and obligate parthenogenesis were realized through an array of cell cycle mutants (both meiotic and mitotic), triggered by hybridization and all differing from those of nonhybrid parthenogenesis of ancestors (reviewed in Scali et al., 1995).

Present hybridization results seem also to indicate that eggs laid by parthenogenetic females do not realize amphimixis as easily as those laid by females of bisexual populations. Furthermore, we could estimate that in some amphimictic egg batches with high hybridization rate $(\mathrm{C} 9,10$, Table 1$)$ about 30 per cent of hybrid embryos die out, as egg average hatching reaches 58 per cent, instead of the 88 per cent of the homospecific $r r \times r r$ crosses, involving either amphimictic or parthenogenetic females (Bullini, 1965; Scali, 1968). In this connection, the lack of hybrids in the offspring of the $\mathrm{C} 14$ cross, together with its low hatching (Table 1), could be explained by a complete developmental failure of actually formed hybrid zygotes, as cytological checking of unhatched eggs revealed that half of them started developing and 10 per cent reached completely formed, ready-to-hatch embryos.

Fertilization of eggs laid by parthenogenetic females, although lower on average, is highly variable (0-63.4 per cent); such a wide range appears to be related to individual differences rather than to the geographical origin (syntopic or allopatric) of the mothers. It appears that differential reinforcement mechanisms against heterospecific fertilization of parthenogenetic females have not developed in syntopy vs. allopatry. Thus, Bacillus stick insects differ from the geographical strains of Tribolium castaneum, whose hybrid yield is highly straindependent when mated in reciprocal crosses with $T$. freemani (Wade \& Johnson, 1994).

The higher proportion of hybrid females than of hybrid males suggests a preferential survival of $\mathrm{X}$-bearing gametes and/or XX embryos; the postzygotic and, possibly, gametic isolation is strong enough to prevent hybridogenetic strains of $B$. rossius-grandii benazzii being produced currently in syntopy.
The production of androgenetic descendants from hybrid eggs clearly reveals that the grandii genome can successfully exploit the hybrid egg cytoplasm; conversely, backcross failure should be mainly because of the gametogenetic impairment of hybrid females. Furthermore, natural B. grandii androgens could possibly promote the evolution of the paternal species, as they re-enter the parental gene pool while carrying the maternal rossius mitochondrial DNA.

Finally, a widespread unidirectionality or asymmetry of hybridization crosses has been repeatedly observed, with one species invariably (or mainly) acting as the maternal and the other as the paternal ancestor. Even if this peculiarity can be understood in some instances in terms of behavioural and/or developmental constraints, it is still unexplained in the great majority of interspecific hybrids (Bullini, 1985; Dawley \& Bogart, 1989; Avise et al., 1992). In $B$. rossius $\times B$. grandii hybrids, $B$. rossius has always been the maternal taxon; however, this asymmetry could be an artefact, if, as present day demography suggests, only all-female populations of $B$. rossius came into contact with bisexual $B$. grandii.

\section{References}

AVISE, J. C., QUATTRO, J. M. AND VRIJENHOEK, R. C. 1992. Molecular clones within organismal clones: mitochondrial DNA phylogenies and the evolutionary histories of unisexual vertebrates. In: Hecht, M. K., Wallace, B. and MacIntyre, R. J. (eds) Evolutionary Biology, vol. 26, pp. 225-246. Plenum Press, New York.

BULLINI, L. 1965. Ricerche sulle caratteristiche biologiche della anfigonia e della partenogenesi in una popolazione bisessuata di Bacillus rossius (Rossi) (Cheleutoptera $=$ Phasmoidea). Riv. Biol., 58, 189-216.

BULLINI, L. 1985. Speciation by hybridization in animals. Boll. Zool., 52, 121-137.

BULlini, L. 1994. Origin and evolution of animal hybrid species. Trends Ecol. Evol., 9, 422-426.

BULliNI, L. AND NASCETTI, G. 1990. Speciation by hybridization in phasmids and other insects. Can. J. Zool., 68, 1747-1760.

CIMINo, M. C. 1972. Egg-production, polyploidization and evolution in a diploid all-female fish of the genus Poeciliopsis. Evolution, 26, 294-306.

COYNE, J. A. 1994. Rules for Haldane's rule. Nature, 369, 189-190.

DAREWSKY, I. S. 1983. Origin of the unisexuality and hybridogenous speciation in vertebrate animals. $A b h$. Akad. Wiss. DDR Abt. Math. Naturwiss. Tech., 14, 75-82.

DAWLEY, R. M. AND BOGART, J. P. 1989. Evolution and ecology of unisexual vertebrates. New York State Museum Bull., 466, 1-302. 
Drosopoulos, s. 1978. Laboratory synthesis of a pseudogamous triploid "species" of the genus Muellerianella (Homoptera, Delphacidae). Evolution, 32, 916-920.

MANTOVANI, B. AND SCALI, V. 1992. Hybridogenesis and androgenesis in the stick-insect Bacillus rossius-grandii benazzii (Insecta, Phasmatodea). Evolution, 46, 783-796.

MANTOVANI, B. AND SCAL1, v. 1993. Ecological, genetic and phyletic characterization of Bacillus grandii maretimi ( $\mathrm{n}$. subsp.) (Insecta Phasmatodea). Vie et Milieu, 43, 241-246.

MARESCALCHI, O., PIJNACKER, L. P. AND SCALI, V. 1991. Cytology of parthenogenesis in Bacillus whitei and Bacillus lynceorum (Insecta Phasmatodea). Inv. Repr. Dev., 20, 37-43.

MORITZ, C., BROWN, W. M., DENSMORE, L. D., WRIGHT, J. W., VYAS, D., DONNELlan, S. ET AL. 1989. Genetic diversity and the dynamics of hybrid parthenogenesis in Cnemidophorus (Teiidae) and Heteronotia (Gekkonidae). In: Dawley, R. M. and Bogart, J. P. (eds) Evolution and Ecology of Unisexual Vertebrates. New York State Museum Bull., 466, 87-112.

NASCETTI, G. AND BULL1N1, L. 1982. Bacillus grandii n. sp. and $B$. whitei n. sp.: two new stick-insects from Sicily (Cheleutoptera, Bacillidae). Boll. Ist. Entomol. Univ. Bologna, 36, 245-258.

NASCETT1, G., BIANCHI BULLINI, A. P. AND BULlinI, L. 1985. Speciation by hybridization in the stick insects Bacillus white $i$ and B. lynceorum (Cheleutoptera, Bacillidae). Atti Assoc. Genet. Ital., 31, 135-136.

QUATTRo, J. M., AVISE, J. C. AND VRIJENHOEK, R. C. 1992. Mode of origin and sources of genotypic diversity in triploid fish clones (Poeciliopsis: Poeciliidae). Genetics, 130, 621-628.

SCALI, v. 1968. Biologia riproduttiva del Bacillus rossius (Rossi) nei dintorni di Pisa con particolare riferimento all'influenza del fotoperiodo. Atti Soc. Tosc. Sc. Nat. Mem., 75, 108-139.
SCALI, V. AND TINTI, F. 1992. Rapid assessment of maturation stage and reproductive mode in centrolecytic eggs of stick insects (Phasmatodea) using DAPI stain. Biotech. Histochem., 67, 356-359.

SCAL1, V., TINTI, F. AND MANTOVANI, B. 1992. From bisexual to unisexual organisms: the case of Bacillus whitei (Insecta Phasmatodea). In: Dallai, R. (ed) Sex Origin and Evolution. Selected Symposia and Monographs UZI, pp 353-368. Mucchi, Modena.

SCALI, V., TINTI, F., MANTOVANI, B. AND MARESCALCHI, O. 1995. Mate recognition and gamete cytology features allow hybrid species production and evolution in Bacillus stick insects. Boll. Zool., 62, 59-70.

SCHARTL, M., INDRAJIT, N., SCHLUPP, I., WILDE, B., EPPLEN, J. T., SCHMID, M. AND PARZEFALL, J. 1995. Incorporation of subgenomic amounts of DNA as compensation for mutational load in a gynogenetic fish. Nature, 373, $68-71$.

SCHULTZ, R. J. 1973. Unisexual fish: laboratory synthesis of a "species". Science, 179, 180-181.

SOKAL, R. R. AND ROHLF, F. J. 1981. Biometry, 2nd edn. Freeman, San Francisco.

TINTI, F. AND SCALl, V. 1992. Genome exclusion and gametic DAPI-DNA content in the hybridogenetic Bacillus rossius-grandii benazzii complex (Insecta Phasmatodea). Mol. Repr. Dev., 33, 235-242.

TINTI, F. AND SCALI, v. 1995. Allozymic and cytological evidence for hemiclonal, all-paternal and mosaic offspring of the hybridogenetic stick insect Bacillus rossius-grandii grandii. J. Exp. Zool., 273, 149-159.

TINTI, F. AND SCALI, v. 1996. Androgenetics and triploids from an interacting parthenogenetic hybrid and its ancestors in stick insects. Evolution, 50, 1251-1258.

WADE, M. J. AND JOHNSON, N. A. 1994. Reproductive isolation between two species of flour beetles, Tribolium castaneum and T. freemani: variation within and among geographical populations of $T$. castaneum. Heredity, 72, $155-162$. 